\title{
Judith Zubieta García, Claudio Rama Vitale (red.), La educación a distancia en México. Una nueva realidad universitaria, Universidad Nacional Autónoma de México, Virtual Educa, México 2015, ss. 253
}

Edukacja na odległość jest zagadnieniem, które spotyka się z dużym zainteresowaniem środowiska naukowego w krajach Ameryki Łacińskiej i Karaibów. Znaczącą rolę w procesie badania i popularyzowania tej formy nauczania odgrywa Virtual Educa, inicjatywa oświatowa powołana do życia w 2001 r. przez Organizację Państw Amerykańskich. W strukturze tego przedsięwzięcia ważne miejsce zajmuje Obserwatorium ds. Edukacji Wirtualnej w Ameryce Łacińskiej i na Karaibach (Observatorio de la Educación Virtual en América Latina y el Caribe), inicjujące wiele ciekawych projektów wydawniczych. Na szczególną uwagę zasługuje seria publikacji poświęconych rozwojowi kształcenia na odległość w poszczególnych krajach regionu. Zbiorowych monografii doczekały się Ekwador (La educación a distancia y virtual en Ecuador. Una nueva realidad universitaria, 2013), Peru (La educación a distancia en el Perú, 2013), Kolumbia (La educación superior a distancia y virtual en Colombia: nuevas realidades, 2013) oraz Puerto Rico (Informe: Educación virtual y a distancia en Puerto Rico, 2014). Publikacje te są efektem współpracy Obserwatorium $z$ lokalnym środowiskiem naukowym. Za ich wydanie odpowiedzialny jest każdorazowo jeden z krajowych uniwersytetów zasłużonych dla wdrażania edukacji zdalnej. Cechą charakterystyczną jest również fakt, iż obok Urugwajczyka Claudia Ramy Vitalego, dyrektora Obserwatorium, redakcji naukowej podejmują się badacze reprezentujący kraj, którego dana publikacja dotyczy.

W ostatnim czasie ukazały się dwie nowe monografie wpisujące się we wspomniany cykl. Jedną z nich dedykowano Meksykowi (La educación a distancia en México. Una nueva realidad universitaria, 2015), drugą zaś wybranym krajom Ameryki Środkowej i Karaibów (La educación a distancia 
y virtual en Centroamérica y el Caribe, 2016). Niniejszy tekst odwołuje się do pierwszej z tych prac.

„Kształcenie na odległość w Meksyku. Nowa rzeczywistość uniwersytecka" to publikacja wydana przez największą latynoamerykańską uczelnię wyższą, Universidad Nacional Autónoma de México (UNAM). Redaktorami książki są wspomniany tu już wcześniej Claudio Rama Vitale oraz meksykańska badaczka Judith Zubieta García - koordynatorka systemu edukacji otwartej i kształcenia na odległość w tejże instytucji. W pracy zamieszczono 14 artykułów, których autorzy wywodzą się z UNAM oraz innych ośrodków akademickich, m.in. z Benemérita Universidad Autónoma de Puebla, Universidad de Guadalajara, Universidad Veracruzana oraz Instituto Politécnico Nacional. Poszczególne teksty zostały przyporządkowane do trzech bloków tematycznych.

Pierwsza część książki ukazuje historię kształcenia na odległość w Meksyku, ze szczególnym uwzględnieniem doświadczeń rodzimego szkolnictwa wyższego. Czytelnik ma okazję dowiedzieć się, kiedy poszczególne uczelnie rozpoczęły wprowadzanie do swej oferty pierwszych programów realizowanych na odległość oraz poznać genezę tworzenia się wyspecjalizowanych jednostek uniwersyteckich odpowiedzialnych za tę formę kształcenia. Rysowi historycznemu towarzyszy tekst omawiający uwarunkowania prawne edukacji zdalnej w Meksyku. Dopełnieniem poruszanej problematyki jest próba określenia profilu studentów korzystających z tej formy kształcenia.

Teksty zamieszczone w drugiej części publikacji koncentrują się na wyzwaniach oraz perspektywach rozwoju meksykańskiego kształcenia na odległość. Poruszona zostaje problematyka umiędzynarodowienia studiów wyższych oraz krajowej współpracy międzyinstytucjonalnej. Działania w obu tych wymiarach wspiera ECOESAD (Espacio Común de Educación Superior a Distancia), sieć rodzimych uczelni zaangażowanych w rozwój edukacji zdalnej, o czym traktuje jeden z tekstów. W niniejszej części poświęcono również dużo miejsca roli, jaką kształcenie na odległość odgrywa w procesie regionalizacji szkolnictwa wyższego w Meksyku oraz pozostałych krajach latynoamerykańskich. Jednocześnie zwraca się uwagę na przeobrażenia, jakie zachodzą w tej kwestii wraz z postępującą wirtualizacją edukacji i odchodzeniem od tradycyjnego kształcenia na odległość w trybie blended-learning.

Publikację zamyka część poświęcona nowym zjawiskom w obrębie edukacji zdalnej. Przedmiotem refleksji stają się m.in. Masowe Otwarte Kursy Online (Massive Open Online Courses - MOOCs). Czytelnik książki ma okazję zapoznać się z doświadczeniami meksykańskich - oraz w szerszym 
kontekście latynoamerykańskich - uczelni biorących udział w tego typu projektach.

Z kart niniejszej książki wyłania się obraz kraju posiadającego długie tradycje w kształceniu na odległość, szczególnie na poziomie szkolnictwa wyższego. Uwarunkowania geograficzne oraz społeczno-ekonomiczne Meksyku sprawiają, iż podjęcie studiów obarczone jest wieloma trudnościami, wyrzeczeniami i kosztami natury finansowej. Możliwość korzystania z oferty akademickiej w trybie edukacji zdalnej otwiera przed dużą częścią zainteresowanych osób nowe perspektywy. Łączenie pracy zawodowej z nauką, bez konieczności zmiany miejsca zamieszkania czy regularnych dojazdów do siedziby uczelni, to niewątpliwie aspekt wpływający na podjęcie decyzji o rozpoczęciu lub kontynuacji kształcenia się. Zastosowanie Internetu w edukacji zdalnej sprawia, iż w trybie tym naukę pobierają coraz to młodsi studenci. Godne podkreślenia jest również zaangażowanie meksykańskich uczelni w inicjatywy pozwalające dotrzeć do większej liczby odbiorców i sprzyjające umiędzynarodowieniu tamtejszego szkolnictwa wyższego.

Artykuły zamieszczone w zaprezentowanej tu publikacji mogą stanowić cenne źródło wiedzy dla osób zainteresowanych rozwojem kształcenia na odległość w krajach pozaeuropejskich. Szczególną wartość w tym kontekście ma blok tematyczny poświęcony genezie edukacji zdalnej w meksykańskim szkolnictwie wyższym. Warto przy tym nadmienić, iż oprócz wydawnictw będących monografiami poszczególnych krajów z inicjatywy Obserwatorium ukazało się wiele publikacji dedykowanych konkretnym problemom kształcenia na odległość w regionie. Odrębnych analiz doczekały się takie zagadnienia jak m.in. niepowodzenia edukacyjne i porzucanie nauki (Deserción en las instituciones de educación superior a distancia en América Latina y el Caribe, 2009), zapewnienie jakości kształcenia (El aseguramiento de la calidad de la educación virtual, 2011), odpowiedzialność społeczna uczelni (La responsabilidad social universitaria en la educación a distancia, 2012), czy proces ewaluacji (Los problemas de la evaluación de la educación a distancia en América Latina y el Caribe, 2015).

Piotr Konieczny 